The Geneva Papers on Risk and Insurance, 22 (No. 82, January 1997) 107-127

\title{
The Phenomenon of Whiplash and the Compulsory Third Party Liability Insurance: An Interim Report from the Netherlands
}

\author{
by F. Th. Kremer and D. van der Kwaak *
}

\section{Introduction}

The increasing degree in which neck injuries are being suffered as a result of traffic accidents gives the Dutch motor insurers rather a lot of worry (and head sores). Not only is the number of neck injuries (hereafter nonetheless to be referred to as "whiplash" increase; also the amounts involved constitute a considerable part (approximated at 35\%) of the total financial burden of motor personal injury claims. In other countries whiplash is also a problem for insurers; in Europe that is especially the case in Scandinavia and Germany. Remarkable, however, is that in these countries whiplash is more of a "quantity problem" (a lot of smaller claims), whereas in the Netherlands it is a "quantum problem". After all, in the Netherlands we regularly come across sizeable claims, sometimes based on $100 \%$ permanent disability; that the Dutch situation differs from in the surrounding countries could very well be helped along by the contemporary views on the legal position of the victim. Because, in whiplash cases we are generally dealing with medically (hardly) nonobjectifiable injuries (often with only subjective complaints such as neck pains, headaches, difficulties with concentration, irritability and sleeping problems; see also the diagram regarding a possible classification Table 2 , chapter 5 , and reasoning from the dictum "the onus of proof rests with the claimant", this could put the victim in a difficult position to prove his case. In practice this problem is not actual, however, especially in view of the broad interpretation of the concept of causation. It is therefore often the liable party (i.e. his third party liability insurer) who has to prove the contrary.

In this article the various aspects of the whiplash phenomenon will be discussed. In chapter 2 some figures and other statistical material will be described; both from the Netherlands and from abroad. In chapter 3 , three questions will be reviewed from a Dutch

* Respectively Head of the Section Special Claims and medical adviser of Nationale Nederlanden General Insurance Company N.V., who hereby wish to thank their colleague Mrs. A.P.H.W. de Mol for her valuable comments on these pages and Mr. E.M.H. Kuijpers for translating this article into English.

1 The word Whiplash refers after all more to the cause of the complaints - the relatively violent movement of the head in relation to the rest of the body - than the symptoms. Whiplash literally means "lash of a whip" and indicates a mechanical movement. A more correct medical description would be "cervicaal acceleratie letsel" (C.A.L.) (Cervical acceleration injury). In England the term whiplash is also used. In Germany, it is referred to as H.W.S. (Harswirbel-säule), Schleudertrauma or H.W.S. Beschleunigungsverletzung. In France the common description is "Coup du lapin". 
viewpoint. The specific legal aspect will be dealt with in chapter 4 , whereas the medical aspect will be addressed in chapter 5. Chapter 6 deals with some aspects of the claim settlements procedure by the insurer. In the concluding chapter 7 there is room for conclusions and recommendations.

Although this article is written from the perspective of the motor insurer, it is realised that it is a social problem too which frequently leaves its mark on the life of its many victims.

Whiplash is a recurrent subject in the national media. ${ }^{2}$ This article attempts to bridge the "popular approach" (by the media) and the scientific approach, with the emphasis on the legal aspect. Simultaneously, it pays attention to the medical, technical and social aspects of whiplash.

\section{Some figures}

The number of whiplash victims in the Netherlands is estimated at 15,000 to 30,000 per year. ${ }^{3}$ Of those, $70 \%$ recover completely within 12 weeks. Most whiplash victims sustain their injury on the roads. It is estimated that $1 / 3$ to $1 / 4$ of the (Dutch) traffic injuries are to the neck. Exact macro-figures are not (yet) available, especially since the present accident statistic in Holland ${ }^{4}$ record injury victims who are immediately recognisable as such, whereas the peculiarity of whiplash is often that the complaints manifest themselves later. For a number of years, at Nationale-Nerderlanden General Insurance Company N.V., the whiplash claims are being registered separately. From this it can be ascertained that there are (per 1st December 1995) 2,159 current whiplash cases; this not only tells us something about an absolute number (numerically in relation to all traffic accidents in any one year), but also about the average "running time" of a whiplash claim. From number of these cases, some specific details have been fed into a PC-programme. From these we learn:

\section{a) Numerically where seated in vehicle

$\begin{array}{lr}\text { Driver } & 445 \\ \text { Front seat passenger } & 139 \\ \text { Rear left seat passenger } & 4 \\ \text { Rear right seat passenger } & 6 \\ \text { Other } & 7 \\ \text { Unknown } & 15 \\ \text { Total } & 616\end{array}$

\footnotetext{
${ }^{2}$ See for example the article on "Modeziekten" (designer illnesses) in HP/De Tijd of 10th March 1995 and the Article "De Nekslag" (Whiplash) in Elsevier of 13th May 1995 and the extensive publicity at the start of the campaign "Voorkom Nekletsel" (Prevent Neck injury) on 1st November 1995 (e.g. ANWB Kampioen, January 1996; pp. $37 / 38$.

${ }^{3}$ See J.S.H.M. Wismans en C.G. Huijskens (TNO) in their report "Incidentie \& preventie van het Whiplash-trauma"; published as appendix 1 to the report on whiplash of the Raad voor de Verkeersveiligheid; January 1995; see also the introduction by S.J. Jonker, Chairman of the Verbond van Verzekeraars (Dutch Insurers' Association), at the start of the campaign Voorkom Nekletsel on 1st November 1995 in Nieuwegein.

${ }^{4}$ For instance the official accident records on the basis of data supplied by the police, compiled by the Dienst Verkeersongevallenregistratie (VOR), which is part of Ministerie van Verkeer en Waterstaat (Ministry of Transport).
} 
b) Numerically in relation to type of collision

$\begin{array}{lr}\text { Rear } & 473 \\ \text { Left } & 46 \\ \text { Right } & 16 \\ \text { Front } & 83 \\ \text { Unknown } & 4 \\ \text { Total } & 624 \\ \text { Numerically to gender } & \\ \text { Male } & 265 \\ \text { Female } & 357 \\ \text { Unknown } & 1 \\ \text { Total } & 623 \\ \text { Numerically to legal representative } \\ \text { Yes } & 282 \\ \text { No } & 250 \\ \text { Total } & 532\end{array}$

At an estimate, ${ }^{5}$ whiplash cost Dutch society some 700 million to 1 billion Dutch guilders in 1995. Of this between 300 and 350 million were for the account of the motor insurers. Two things have to be taken into consideration, however. In the first place this amount is mainly based on reserves on current claims, and secondly a major part is destined for actions of regress (especially Sickness Benefits and Disablement Benefits Act).

In Germany a large scale research was carried out in 1990 into HWS-Beschleunigungsverletzungen,${ }^{6}$ in the course of which 15,000 collisions between two motor vehicles were analysed. In total, whiplash complaints were found in $12,193(=81.3 \%)$ cases. It was ascertained that $68 \%$ of the total claims with respect to traffic accidents were for whiplash injuries. This is considerably higher than in the Netherlands and might be explained, in part, by the fact that in the Netherlands there are many more cyclists (and hence more bicycle accidents), as a result of which the relative number in Holland inevitably has to be lower, because hardly any whiplash injuries are found among injured cyclists, (after all their injuries are unfortunately often more serious). The following statistics are of interest:

5 According to Jonker, loc. cit.

${ }^{6}$ H. Münker, K. Langwieder, E. Chen and W. Hell - HWS-Beschleuningungsverletzungen; eine Analyse von 15000 Pkw-Pkw Kollisionen; Frankfurt/München; 1992. 
Figure 1: The place of first impact in collision with/without whiplash injury $(n=14969)$

\%

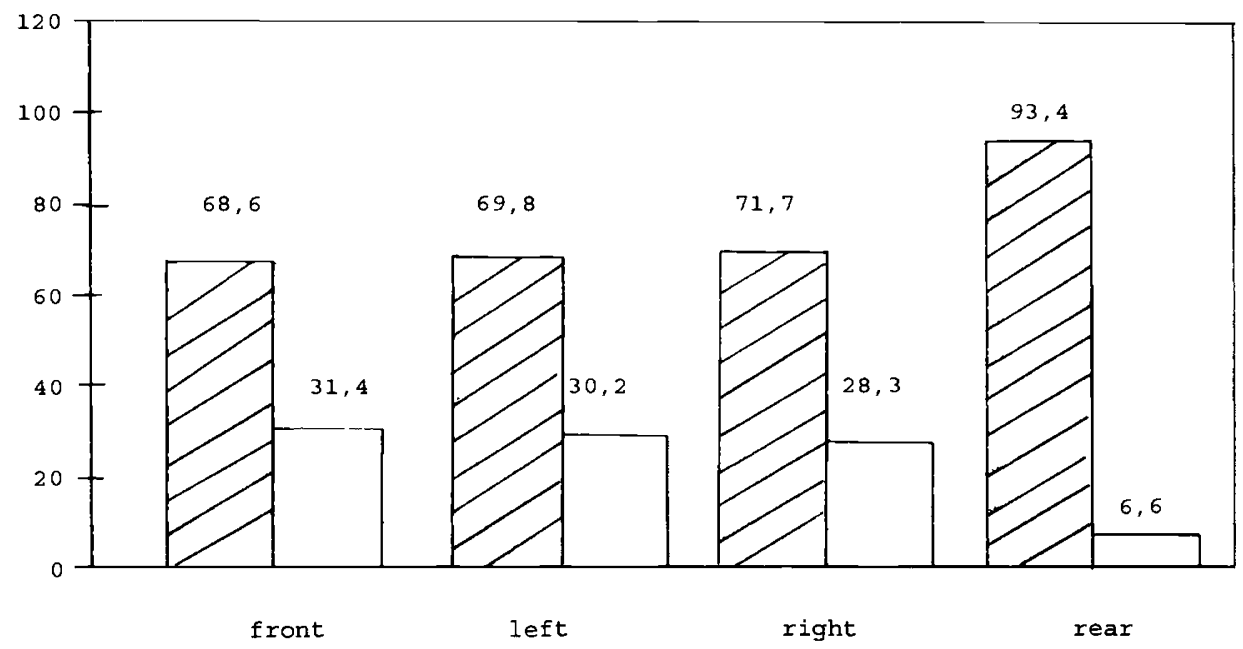

7 with whiplash injury $\quad$ without whiplash injury

Figure 2: Disablement in whiplash injuries $(n=211)$

up to 1 week

1 - 2 weeks

$2-3$ weeks

$3-4$ weeks

4 - 5 weeks

$5-6$ weeks

6 - weeks

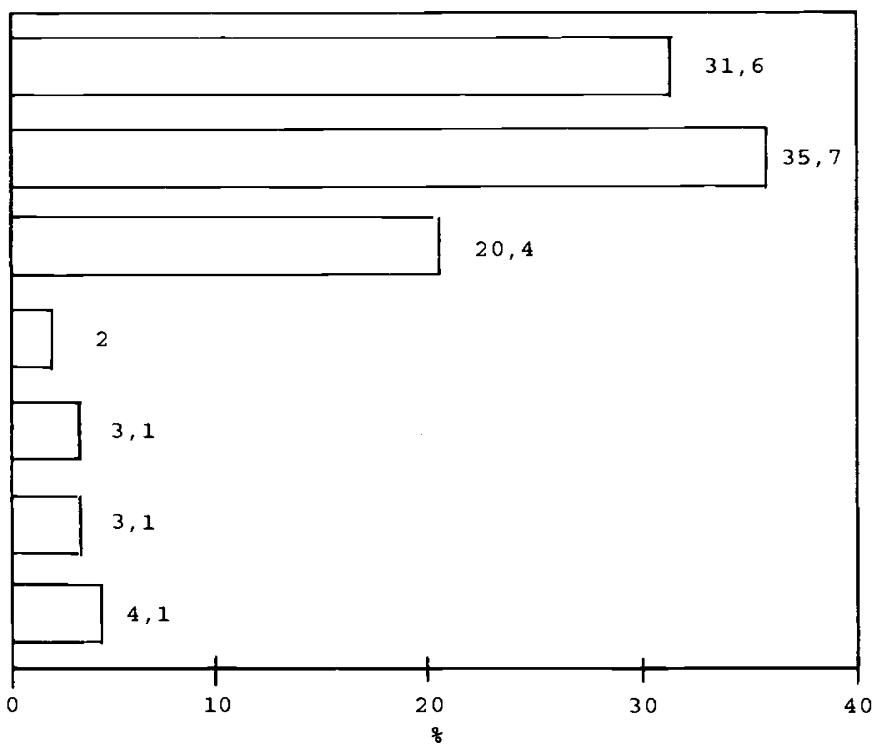


Figure 3: Compensation for pain and suffering $(n=280)$

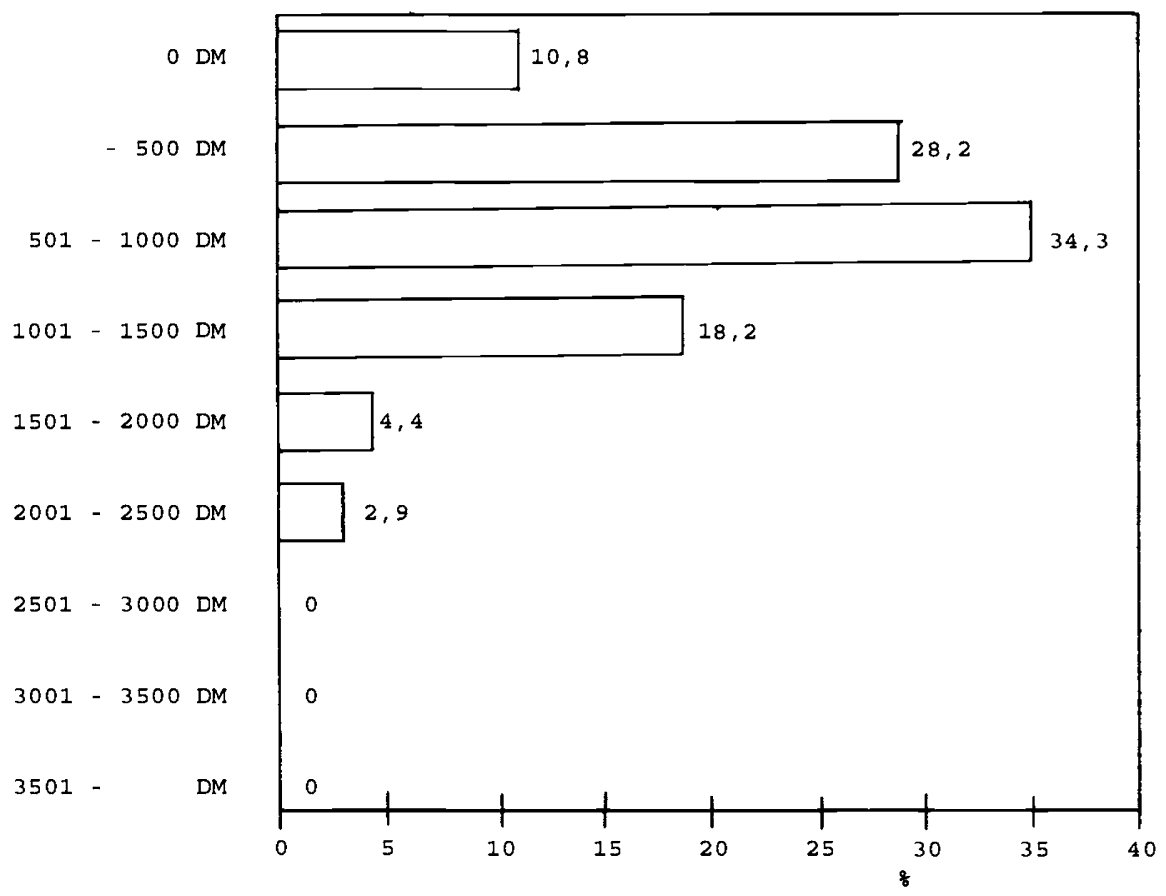

In rear end collisions (so-called Heckkollisionen) there is hence virtually always a claim for whiplash, although it generally concerns limited amounts of compensation. From a survey on whiplash carried out by the Comité Européen des Assurances (CEA) - for the purpose of the meeting of the project group "Sinistres corporels" of 20th January 1993 -, it becomes apparent how diversely European motor insurers view the whiplash problem. The Norwegian answer demonstrates that over $50 \%$ of the personal injuries from traffic accidents are with respect to "whiplash-like claims". The answer from the Verband der Versicherungsunternehmen Österreichs is however completely different and short: "Sur notre marché nous n'avons pas constaté un accroissement de la sinistralité basé sur l'invocation du syndrome "coup du lapin".

That the whiplash problem can even vary within one country is demonstrated by the differing responses from Belgium and the United Kingdom. In Belgium "la région néerlandophone du pays" is specifically mentioned. The British Insurer's International Committe writes: "There has been a growth, throughout the United Kingdom, in claims based on whiplash syndrome. This growth has been particularly marked in Northern Ireland and in the North West of England, specifically centred on Merseyside". In the United Kingdom, 
however, it mainly concerns smaller claims, at least according to case-law. Recent examples are Burke v. Roy of 26.11 '93; Manchester County Court (awarded £13,000.) and Holland v. Wood of $2.7^{\prime} 93$; Torquay County Court $^{7}$ (awarded $£ 15,000$.). In addition there are many awards of amounts lower than $£ 5,000 .^{8}$

The fact that the head restraint is not correctly adjusted can be of great influence in either sustaining or preventing whiplash. To this end the campaign "Prevent neck injury" was started on 1st November $1995 .{ }^{9}$ Research by the SWOV ${ }^{10}$ showed that only $54 \%$ of drivers can adjust the head restraint to an adequate height. It also transpired that even with the head restraint in the highest position, this was still too low for $46 \%$ of the drivers. ${ }^{11}$ Finally it was found by the SWOV that only $26 \%$ of the drivers and $48 \%$ of (front seat) passengers have their head restraints correctly adjusted.

\section{Three interesting questions} be put:

In the light of the whiplash problem in the Netherlands three interesting questions can

a) why are there more female than male whiplash victims?

b) why are whiplash claims so much more prevalent in the last five to ten years than they were previously?

c) why does whiplash pose a bigger (or a different) problem for Dutch insurers than for foreign ones?

\section{Concerning a:}

It is a proven fact that twice as many women sustain whiplash injuries than men. ${ }^{12}$ This is not only the case in the Netherlands, but also in other countries. ${ }^{13}$ This is the more remarkable because of two reasons (which ought to imply the reverse):

- With respect to other traffic related injuries the ratio is $70 \% \mathrm{men} / 30 \%$ women. ${ }^{14} \mathrm{In}$ as far as fatal injuries are concerned, the ratio is more or less the same. So also on the roads the well known saying that "the woman falls ill, the man dies" applies.

- Women in general, are shorter than men and should hence suffer less harmful effects from head restraints that are adjusted too low.

${ }^{7}$ Both cases published in Current Law, Digest May 1994.

${ }^{8}$ See Kemp \& Kemp under E22 Neck; pp. 55056-55081.

${ }^{9} \mathrm{~A}$ joint action by the Verbond van Verzekeraars, Ministerie van Verkeer en Waterstaat, Nederlandse Stichting Whiplash Patiënten, Veilig Verkeer Nederland, ANWB, Ministerie van Welzijn, Volksgezondheid en Sport, the Consumentenbond, BOVAG, RAI, the department Wegtransportmiddelen of TNO and Stichting Wetenschappelijk Onderzoek Verkeersveiligheid (SWOV).

${ }^{10}$ See for instance report R-93-41; see also the introduction by E. Janssen (TNO), at the start of the campaign Voorkom Nekletsel.

${ }^{11}$ In the BOVAG newsletter of 17 th November 1995 it is reported that the Fiat Panda, Renault 19 and Peugeot 205 have head restraints that cannot be properly adjusted.

${ }_{12}$ See chapter 2, table c computer data NN; also see Janssen loc. cit.

${ }^{13}$ See also the German figures, listed in Münker et al, loc. cit.

${ }^{14}$ See Statistisch Jaarboek (Statistical Annual Review) CBS 1995, p. 224 (table 37). 
Various explanations could be proferred as to why many more women sustain a whiplash injury than men. It would be paramount to seek a medical explanation. Men, in general, are more muscular than women; this also applies to the neck. Women, therefore, have a more fragile neck. It is sometimes also suggested that women complain more readily ${ }^{15}$ and have a lower tolerance for pain. Even if this were to be true, it is extraordinary that in as far as other injuries are concerned, men are far in the majority. Another explanation is sometimes sought in the difference in the seating position behind the wheel; men tend to sit a bit more slouched, women on the other hand a bit "stiffer" and consequently with too much room between the head and the head restraint. Whiplash, therefore, as an ergonomic problem. No further research about this is available, however. Because many (day-time) whiplash injuries are sustained in rural areas, the man/woman divergence might also have a sociological background. After all, "most men are at work, while the women are out doing the shopping". This postulation might have been true in the fifties; nowadays there is rather more pluraformity between the sexes in urban traffic (and at work).

Although the aforementioned medical, ergonomic and social aspects will undoubtedly be of some relevance, the main factor would appear to be of a technical nature. Relatively speaking, women - more than men - probably drive smaller cars, generally without safety passenger compartments and without extensive deformation zones and would therefore appear to be more vulnerable to whiplash injuries as a result of rear end collisions. Although this would then also have to apply to other injuries, it must be borne in mind (see chapter 2) that whiplash injuries occur most in low impact rear end collisions (relatively speaking the most common type of collision). The "second car" could hence be the most important trigger for whiplash injuries. Here would then have to lie a (safety-)challenge for the automobile industry.

\section{Concerning $b$ :}

Also with respect to this question, a number of aspects intermingle, namely:

- a road safety/technical aspect

- a sociological aspect

- a legal aspect.

It cannot be denied that our traffic is becoming more and more dense; with more traffic jams and (the necessity for) more traffic lights. This will undoubtedly contribute to the fact that there are more rear end collisions (and therefore more whiplash injuries!) than say 5 or 10 years ago. Apart from this there is another (road) safety/technical aspect: the safety belt. The safety belt has brought about a shift from serious to slight injuries (insofar as whiplash injuries can be quantified as slight injuries at all). Heyer ${ }^{17}$ once typified this very

15 Although this is apparently less than the scientific field assumed; see the article by Suzanne Baart in the Volkskrant of 30th December 1995, Science pages, p. 11.

${ }^{16}$ In the United States whiplash has been known for a long time as the Traffic light syndrome; the whiplash phenomenon has, incidentally, also been recognised in the Dutch medical literature for some considerable time; see for instance the article by R. Braakman (entitled Whiplash) in the Netherlands Tijdschrift voor Geneeskunde (Dutch Journal for Medicine); 120, nr 39, 1976 p. 1634 ff. and the Dutch revision of an American article by G. L. van der Zwaag and F. van 't Hooft named The Whiplash injury in Patient Care, January 1974, p. 4 ff.

${ }^{17}$ In his introduction on the Vermande workshop "Het Whiplash letsel in de letselschadepraktijk" on 31st October 1994 in Utrecht. 
graphically: "In the old days they broke their necks, now they have whiplash". A good head restraint (and possibly an airbag) can hopefully neutralise this - sole - negative effect of the safety belt. The sociological aspect refers in particular to an increasing claim mindedness, combined with a certain "happy in your skin syndrome"; meaning the effort to be "in form" every single day. ${ }^{19}$ This is helped along by "modern" phenomena such as new age, fitness training, vitamin pills and all sorts of alternative medicine. In this - as such positive - quest one is nowadays possibly more alert to (slight) interfering physical symptoms, whereas on the old days one was more readily prepared just to accept this. Some even link this to the secularisation in the Netherlands. The maxim "everybody bears his own losses" 20 is somewhat more compatible with a Calvinistic outlook on life with the aforementioned "happy in your skin syndrome". Whatever the veracity of this, it is a fact that a changed claims behaviour is helped along by the legal aspect. In this context one must think mainly in terms of victim protection in general, a broad interpretation of the concept of causation, and especially the reimbursement of legal expenses in an out of court settlement. In the next chapter this will be dealt with in further detail.

\section{Concerning $c$ :}

It is interesting that whiplash is especially prevalent in countries with a high standard of living and an adequate level of social welfare; e.g. the Netherlands, Germany and the Scandinavian countries. ${ }^{21}$ This can hardly be a coincidence, although maybe especially in these countries there are a lot of "second cars". Apart from this, it can also have something to do with the average height of the nationals of these countries (although statistics from Japan prove that whiplash is not directly linked to height).

Whiplash certainly is not uniquely a Dutch problem (see also the German figures in chapter 2), but in countries such a Germany and Sweden it mainly concerns (a lot of) smaller claims, whereas in the Netherlands approximately $20 \%$ of the whiplash claims are with respect to longlasting disability. In Germany this is significantly lower. ${ }^{22}$ Here too, the legal aspect is of prime importance, however (see hereto also the previous chapter). Especially with regard to causation there exists in many other countries a less victim sympathetic regime than in the Netherlands and the dictum "the onus of proof rests with the claimant" 23

18 Although the airbag apparently causes new victims; see the article by J. B. Schippers et al in the Netherlands Tijdschrift voor Geneeskunde of 23rd December 1995, p. $2661 \mathrm{ff}$. on Cervical avulsion fractures by the airbag.

19 See also the Volkskrant of 5th January 1996, p. 1, reporting a research into trends in lifestyles commissioned by the Ministerie van VROM: "The Dutch people are more and more becoming egocentric bon vivants. They strive after a nicer and more comfortable life and are increasingly less prepared to make sacrifices".

20 Often and more secularly translated as "What can't be cured must be endured".

21 Outside of Europe especially in the United States, Canada and Japan.

22 See chapter 2.

${ }^{23}$ See e.g. in Germany the judgement of the OLG Hamm of 14th April 1994, R + S, October 1994 pp. 379-380: "Der Nachweis, dass ein bei einem Unfall erlitteness HWS-Schleudertrauma zu einem Dauerschade geführt hat, ist trotz der Beweiserleichterungen des Par. 287 ZPO nicht erbracht, wenn die Unfallabhängige Entstehung der behaupteten Beschwerden nicht wahrscheinlicher ist als ihre unfallunabhängige Entstehung". 
applies there, especially in the more substantial claims. Further study into this is certainly warranted, because it will not only apply to whiplash injuries, but also to other medically non-objectifiable complaints. ${ }^{23}$ It is therefore satisfying to learn that the Dutch Insurers' Association (Verbond van Verzekeraars) has commissioned the Rand-Organisation, in collaboration with the Technical University Delft, to carry out a whiplash research in which attention will be given to these differences between the Netherlands and other countries.

\section{Legal aspects}

In order for any claim for compensation by a victim to succeed there still applies the condition that there needs a negligent party; in cases of a road accident related whiplash injury, this generally does not pose a problem. There exists after all a dual possibility which will turn the search for a liable party virtually always into a success:

a) the injured passenger holds the driver responsible. Even if another vehicle is involved - with possibly (contributory) negligence on the other driver's side - the passenger can still hold the driver (of the car in which he was a passenger) liable for his total damages; he can do so on the grounds of the co-authorship as laid down in article 6:102 of the Civil Code. Additionally there the possibility on the basis of the Innocent Third Party agreement to which the market has agreed, and about which agreement the Raad van Toezicht op het Schadeverzekeringsbedrijf (Regulatory body for the General Insurance Industry $)^{24}$ has recently ruled that an innocent passenger is also deemed a third party. In the eventuality of a one-vehicle accident, the passenger will only be unsuccessful in case of complete absence of negligence on the side of the driver, e.g. an accident as a result of suddenly slippery road conditions for which the driver cannot be reproached;

b) the injured driver holds the driver of the following vehicle liable. Such an action is more or less based on strict liability; the assumption that the driver of the following vehicle did not keep sufficient distance. ${ }^{27}$

Having established that there is virtually always a liable party in the case of a whiplash injury, the application of article 6:96 paragraph 2 of the Civil Code subsequently comes into operation: the legal costs in an out of court settlement. ${ }^{28}$

The reimbursement of legal costs in an out of court settlement is also a reason for the increase referred to in chapter 3 under $b$. Now that it would appear reasonable as such for a whiplash victim to turn to a legal representative (who consequently does not need to wage

${ }^{24}$ Such as Repetitive Strain Injury, Organic Brain Disorder, Post Traumatic Stress Syndrome and the Sick Building Syndrome.

${ }^{25}$ The RAND-Organization is an American non-profit research institute; the research in question is carried out by the daughter organization The European American Center for Policy Analysis (EAC).

${ }^{26}$ In RvTnr. III-94/20, it was decided that a passenger who - through no fault of his own - suffered damages as a result of a car accident - must get his entire loss reimbursed by the third party liability insurer whom he has addressed for compensation (with subsequent settlement between the insurers, based on the degree of liability).

${ }^{27}$ See for example Hof Amsterdam, 21st July 1975; VR 1984, nr. 22.

28 Already accepted in HR 3rd April 1987, NJ 1988, 275 (London \& Lancashire/Drenth), in anticipation of art. 6:96 BW; see also F. TH. Kremer "Moeten alle buitengerechtelijke kosten vergoed worden; en zo ja, waaron niet?" (Must all costs of legal assistance be reimbursed, and if yes, why not?), Salomonsbundel, 1991 ; p. 25 ff. 
the liability battle), a true "lawyers paradise" has come into existence in the Netherlands, in which all kinds of legal representatives offer their services through adverts in newpapers, leaflets in waiting rooms of G.P.'s doctors and paramedics and sometimes even through offering bonuses for referring a victim. If there are any American situations in the Netherlands at all, then it must surely be in this field. It is therefore the combination of:

- an easily identifiable liable party

- reimbursement of legal costs

- sympathy for the victim, both from the legislator and the courts

which would explain the large number of whiplash claims for Dutch insurers, and could at the same time be one of the reasons why in this respect the Dutch situation differs from many other countries. This is, in particular, connected with the Dutch idea(s) on causation. There is a tendency in legal history to let the insurer bear any uncertainty about causation. ${ }^{29}$ Not only the question of establishing negligence, but also of the attribution of the extent of compensation is generally decided entirely in the favour of the victim. Neither a rare physical nor mental abnormality (predisposition) can, on the face of it, break this causal connection; this applies to the same degree for problems in the personal sphere. ${ }^{30}$ This is subsequently underpinned with the English saying: "The tortfeasor must take the victim as he finds him. ${ }^{31}$ In a ruling by the Dutch Supreme Court in ABP v. Van Stuyvenberg of 4th November 1988 , NJ 1989, 751, this has been unequivocally confirmed and is defended by Brunner in his annotations to this ruling:... "It is not fitting to attribute the more than average good condition of the victim to the credit of the negligent person and to attribute the especially vulnerable condition of the victim to his disadvantage". Even where psychological injuries are concerned the Supreme Court seems to be moving in that direction. ${ }^{32}$ The Dutch view on causation is embedded in article 6:98 of the Civil Code: attribution in reasonableness. In this, a greater attribution takes place in personal injuries cases than in those involving material damage ${ }^{33}$; this oppresses even more where traffic and safety norms are breached $^{34}$; this concept, however, was already confirmed more than 15 years ago by the Supreme Court in Vader Versluis v. Ziekenzorg of 2nd November 1979, NJ 1980, 77 (G.J.S.). To that extent the complete attribution in whiplash claims seems to fit in with the current doctrine.

Noteworthy, however, is the fine distinction Hartlief ${ }^{35}$ makes about the question of legal attribution, in which he differentiates between "inflicting personal injury" and "causing personal injury". With regard to the latter category (to which category the whiplash

${ }^{29}$ See also Verzekering en de groeiende aansprakelijkheidslast, edited by M. G. Faure andT. Hartlief; Kluwer Deventer, 1995, p. 24 and the literature mentioned there.

${ }^{30}$ See Faure/Hartlief, loc. cit. p. 28.

${ }^{31}$ See also J.H. Wansink, Causaliteit en (on)verzekerbaarheid, discourse at the Houthoff seminar on 28th September 1995; published in "Is verzekeren nog verzekerd?", p. 16, Tjeenk Willink Zwolle, 1995.

${ }^{32}$ See HR 1st July 1993, NJ 1993, 667 (P.A.S.); Stichting Administratie Centrum Haaglanden Nuts/Hofman.

${ }^{33}$ See C.J.H. Brunner, Causaliteit en toerekening; VR 1981, p. $210 \mathrm{ff}$.

${ }^{34}$ See T. Hartlief, "Causaliteit. Over de grenzen aan de toerekening bij Letselschade", introduction at the LSA-congress 1995; published in Bijzonder Letsel, Vermande, 1995, pp. 34-35.

${ }^{35}$ Faure/Hartlief, loc. cit, pp. 34-35. 
claims will in general actually belong) there is then room for a less far-going attribution. Wansink ${ }^{36}$ subscribes to this position, especially where psychological injuries are concerned: "Is it after all not appropriate, particularly with psychological injuries, to exercise great restraint to assume, on the basis of presumptions, a causal connection with a certain action of a third party, given the fact that the distinction between an already existing mental (in-)disposition ... is hard to determine?"

In this respect the verdict of the OLG Hamm of 14th April 1994, mentioned in chapter 2 is referred to, in which, within the framework of paragraph $287 \mathrm{ZPO}$ (the German article on causation), it was considered that the victim had not proven his case, if there was another possible cause: "Der Nachweis ist nicht geführt, wenn eine unfallbedingte Verletzung nicht wahrscheinlicher ist, als einunfallunabhängige".

It therefore remains the question whether a complete attribution in case of whiplash claims is always that reasonable; naturally seen from the position of the responsible third party, respectively his third party liability insurer. The following arguments (and especially a combination thereof) make out a case for a less far-going attribution, i.e. an ota degree of contributory negligence:

a) In many rear end collisions there exists only a small degree of fault (in the sense of negligence). Nonetheless, mitigating circumstances can still be derived from this. ${ }^{37}$ Additionally there is the question to what extent one can really speak in terms of a breach of traffic or safety norms in cases of classic rear end collisions. In particular, this is interesting in a case where the victim was not protected by a correctly adjusted head restraint. The question can thus be asked who in fact committed the greater breach of a safety norm: the driver of the colliding vehicle or the victim. This consideration becomes even more pertinent as more publicity is given to unsafe headrest supports (for example the recently erected billroad posters by the side of the roads). Could such an unsafe head restraint then not constitute a circumstance which can be attributed to the victim on the ground of article 6:101 of the Civil Code? Or would the reasonableness still preclude this?

b) In practice it is found that especially with whiplash claims, there is more often a certain predisposition, respectively difficulties in the personal field. There also exists a tendency toward the so-called "stepping stone syndrome", 38 whereby all complaints and abnormalities which are encountered after the accident are attributed to this accident, whereas these can of course have other non-accident related causes.

c) Whiplash is a so-called medically non-objectifiable injury, in that the diagnosis is made mainly on the basis of the victim's complaint pattern. The question therefore arises whether this is entirely in correlation with a complete attribution. In the scarce jurisprudence on whiplash, this has not yet been the issue. In a recent case on the subject, (Rechtbank Utrecht: KG 27th June 1995, VR 1996, nr 205) the issue was quantum rather than (medical) causation.

${ }^{36}$ Loc. cit., pp. 17-18.

${ }^{37}$ See Faure/Hartlief, loc. cit., p. 33.

38 This syndrome is also cited in the interview with Kees and Ineke Lambers in the Volkskrant of 23rd December 1995; supplement p. 3. 
A reassessment of the rule "the onus of proof rests with the claimant" would therefore merit contemplation, especially where long term disability is concerned. This would be in line with the French practice, which makes a distinction between Incapacité Temporaire (ITP) and Incapacité Permanente (IPP). Whiplash, falling into the category "traumatismes du rachis" ${ }^{39}$ is generally appraised under this graded system with a "taux d'IPP" of $3 \%-5 \%$, albeit that a full compensation of the loss of income is temporarily possible under the ITP. In as far as the burden of proof is concerned, the German rulings on Par. $287 \mathrm{ZPO}$ (whereby a mitigation of the burden of proof for the claimant does, in principle, exist) provide some examples. ${ }^{40}$ Even in the Swiss literature, doubts are voiced on a too broad interpretation of causation. Steinegger ${ }^{41}$ in this context states: "Die Adäquanzbeurteilung verkommt zur reinen Lotterie bzw. hängt davon $\mathrm{ab}$, wie gut es einem Geschädigten gelingt, seine subjektiven Beschwerden "glaubhaft" darzustellen". Art. 6:101 of the Dutch civil code could therefore be a mitigating factor. Van Dam ${ }^{42}$ argues that the primary function of the law of tort is not the compensation of the loss, but the establishment of the right equilibrium between the various objectives: prevention, compensation and distribution of loss. With whiplash claims, this equilibrium will have to be found in the jurisprudence. It must be borne in mind that a low threshold to the entrance to the "money pit" acts as an invitation for abuse; this applies the more with regard to complaints which are not (directly) objectifiable; the history of the Disablement Benefits Act (WAO) has certainly taught us that.

A too low threshold to the system of compensation can also endanger the (boundaries of) insurability. ${ }^{43}$ The (necessary) premiums must after all remain determinable and affordable.

\section{Medical aspects}

For years now it has been attempted in vain by means of many symposia, conferences and articles to reach medical consensus on the subject of immediate care and treatment of people with complaints following a rear end collision and especially people with the socalled chronic post-whiplash syndrome. This stalemate now seems in the process of being broken. In the past years, two articles which merit attention have appeared in two leading international medical journals. In "Neurology 45 " the article Polemics of chronic whiplash

${ }^{39}$ See Barème indicatif des déficits fonctionnels séquellaires en droit commun; Le Concours Médical, p. 17 ff.

40 See for example LG Osnabrück of 22nd April 1994, nr. 30245/93 (not published) and OLG Karlsruhe of 19th April 1995, nr. 1U204/94 (not published).

${ }^{41}$ Rolf P. Steinegger, das "Schleudertrauma” der Halswirbelsäule - Stand der Diskussion; Schweizerische Zeitschrift für Sozialversicherung, nr. 4/1995, p. 274.

42 C. C. Van Dam, Zorgvuldigheidsnorm en Aansprakelijkheid; dissertation Utrecht, Deventer 1989 , p. 253.

${ }^{43}$ The Verbond van Verzekeraars organized a congress on this on 16th February 1995, during which causation was also discussed.

${ }^{44}$ See also Faure/Hartlief, loc. sit. p. 37.

${ }^{45}$ Neurology 1994, nr. 44 p. 1993 ff. 
injury, by J.M.S. Pierce, featured as an editorial. In this article Pierce critically comments on the chronic post-whiplash syndrome. In Spine ${ }^{46}$ appeared - as supplement - a summary of the report published by the "Quebec Task Force". ${ }^{47}$

What is now the value and relevance of these two articles for the Netherlands? The article by Pierce might only prompt the reader to reflect; the report by the Quebec Task Force, however, spurs him into action.

The report has been compiled after many years' research by Canadian and European researchers into the phenomenon of whiplash. They not only addressed the medical consequences of whiplash, but also occupied themselves with advice on prevention, for example in the fields of car safety and traffic technical situations. Further, they pursued economical consequences, which are, for the main part, founded on legal and traffic technical grounds. At the latest national NSWP congress, which took place on 4th October 1995, the medicalscientific council of the NSWP (i.e. the Dutch Association of Whiplash Patients) made it known that it was in complete agreement with the protocol of immediate care and treatment as described in said report. On 17th November 1995, at a conference in the Academic Medical Centre, the Dutch situation was evaluated from the structural perspective provided by the Quebec Task Force. ${ }^{49}$ In view of these parameters it is deemed necessary to dedicate ourselves, in the short term, not only to make the findings of the report under discussion known to members of the medical profession/personal injury technicians who might be confronted with this problem, but also to its implementation.

A few million people go through the experience of a rear end collision as passenger in a motor vehicle every year. The complaint patterns that these people may develop is identical all over the world.

Very different, however, is:

- the claims behaviour

- the (immediate) medical care

- the medical or paramedical treatment

- the assumed long term temporary or permanent diminished disability, borne out by benefits awarded.

In the Task Force report a number of traffic technical recommendations in order to prevent whiplash are given. These include:

- recommendations on the prevention of accidents, for example by a more stringent selection for issuing or renewing driving licences;

- recommendations on studies to improve road safety;

- recommendations that should lead to research into the development of a safer car, especially in as far the car seat and the appurtenant head restraint is concerned.

${ }^{46}$ Spine April 1995, Volume 20, number 8/S.

${ }^{47}$ Namely Whiplash- Associated Disorders (WAD), submitted by the Quebec Task Force on WAD; Walter O. Spitzer, chairman (january 1995).

48 The Nederlandse Stichting Whiplash Patiënten.

${ }^{49}$ See the congress-paper "Beoordeling van de gevolgen van het cervicaal acceleratieletsel"; Amsterdam, November 1995. 
The claims behaviour can differ per country, or, as in Canada, per state. This can have something to do with medical-biographical, legal and economic factors.

From the Canadian study the following recommendations and conclusions in the medical field can be drawn ${ }^{50}$ :

- recommendations for research into the effects of medical biography and socio-economic aspects on the claims behaviour of victims;

- recommendations on immediate medical care and treatment following a standardized protocol;

- the conclusion that immobilisation/too much rest has a negative effect on the disappearance of complaints and resumption of work $;^{51}$

- the factual conclusion that until today not a single research has borne out that any treatment whatsoever yields a better result than the advice to mobilize. The case is even made that people who are advised to mobilize, get rid of their complaints quicker than those undergoing some therapy or another.

For the immediate medical care and physical examination the Task Force not only drew up a guide for a classification in grades, based on the severity of the symptoms, but additionally Guidelines for treatment.

From the report by the Task Force ${ }^{52}$ it transpires, as already mentioned, that in a country like Canada the claims pattern varies enormously in the different states. But in spite of this great difference in claims pattern - with consequently great differences in the number of whiplash patients - it also appears that after one year the disability percentage in the various states does not vary. In all states this appears to be less than $2 \%$. If the fact is also taken into account that only part of this whole group has been given the correct advice to stay active, the implication is that this percentage should become even lower. After all, immobilization and a number of other forms of therapy lead to a worse result where employment reintegration is concerned. In Canada, almost $58 \%$ of whiplash victims were completely back at work after six weeks and $98.3 \%$ after one year. The figures for Germany show an even quicker recovery. In Germany where, as already mentioned, almost $80 \%$ of the people who have experienced a rear end collision, file a claim, $9 \%$ is (partly) disabled after 3 months and after one year the percentage is negligible. ${ }^{53}$ Very recent research and statistics from Dutch insurance companies has shown that after one year and at an estimate, more than $20 \%$ of the whiplash patients who are medically known, are considered disabled to a degree by treating physicians and the supervisory bodies. More than $10 \%$ receive benefits under the Disablement Benefits Acts, implying that their absenteeism has lasted longer than one year. Apart from that there is an even larger group which receives benefits for the established disability, as a result of which one would be less self productive and in need of domestic help for very long periods of time. The present routine in the Netherlands is as follows.

\footnotetext{
${ }^{50}$ Loc. cit.; Section 7, p. 4 ff.

${ }^{51}$ See also loc. cit.; chapter 5.3.3. pp. 3-4.

${ }^{52}$ Loc. cit.; Section 6, p. 12 ff.

${ }^{53}$ See also Münker et al., loc. cit.
} 
Table 1: Quebec Task Force on whiplash-associated disorders

The Quebec guidelines for patient care*
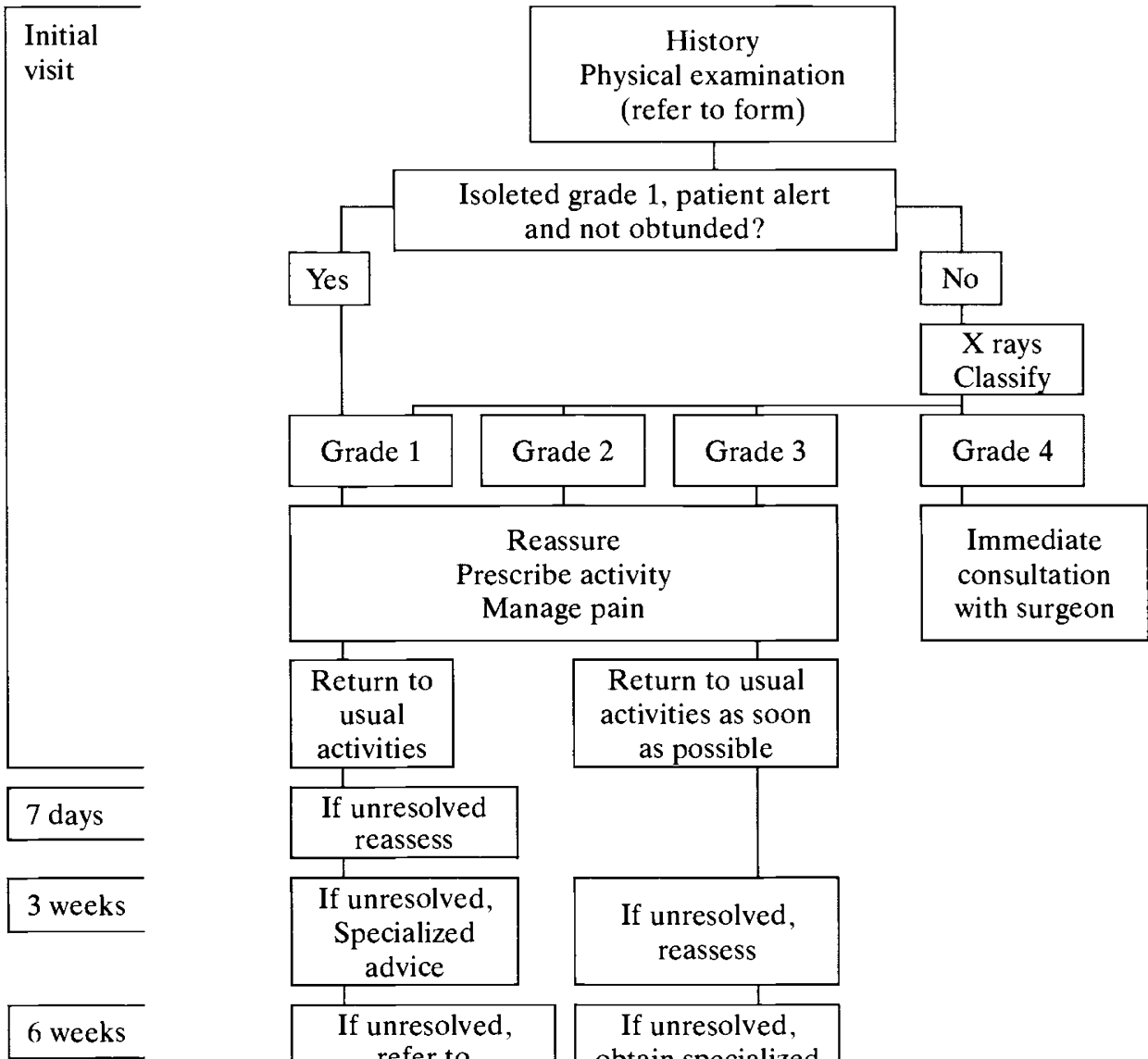

If unresolved, Specialized advice

If unresolved, refer to multidisciplinary team

Return to usual activities as soon as possible

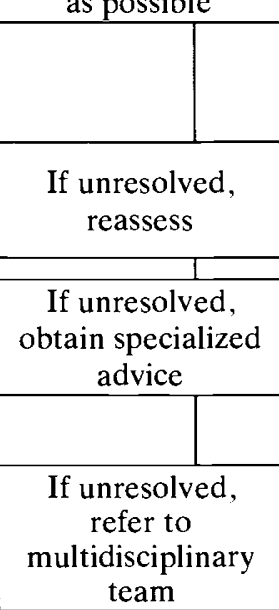

* See operational definitions for explanation of terms. 
Table 2:

Quebec Task Force on whiplash-associated disorders

Proposed clinical classification of whiplash-associated disorders

Grade Clinical presentation

$0 \quad$ No complaint about the neck

No physical sign(s)

$1 \quad$ Neck complaint of pain, stiffness or tenderness only

No physical sign(s)

2 Neck complaint

AND

Musculoskeletal sign(s) $\left.{ }^{*} 1\right)$

$3 \quad$ Neck complaint

AND

Neurological sign(s)

4

Neck complaint

AND

Fracture or dislocation

*1) Musculoskeletal signs include decreased range of motion and point tenderness.

*2) Neurologic signs include decreased or absent deep tendon reflexes, weakness, and sensory deficits.

Symptoms and disorders that can be manifest in all grades include deafness, dizziness, tinnitus, headache, memory loss, dysphagia, temporo-mandibular joint pain.

Dotted lines indicate limits of terms of references of Task Force. 
On the basis of the complaints voiced by the patient, the company doctor or review doctor establishes that an illness or disorder lies at the base of the complaint pattern. The claimant can automatically tie this in with a certain degree of disability, which may lead to a (temporary) partial ot (temporary) complete disability, or to diminished possibilities to perform activities outside of a contract of employment. Simply but succintly put: In the Netherlands complaints lead to illness ... an illness leads to the legitimation of a diminished performance ... a diminished performance leads to incapacity to work, in this case disability. This seems to have become almost a given fact.

A general practitionner with an average sized practice will, in view of the figures given, possibly see some five new (whiplash) patients per year in his surgery. Of these, more than one will become disabled, either for a long period of time or permanently. As medical adviser for an insurance company, one can figuratively speaking see this disability being born in the following manner: A patient visits a doctor's surgery with the usual complaints ... to the patient's mind he is either not given sufficient attention or he feels misunderstood ... this leads to an ever increasing lack of understanding ... the patient wants to seek a specialist opinion or, because of an increasing feeling of discomfort, he hides in the alternative medical circuit, where, in his opinion, adequate attention is given to his complaints ... this "hiding away" often lasts too long ... and leads to a difficult or even impossible partial or complete reintegration in the employment process. From the above it can be concluded that unnecessary invalidity can only be prevented, if GPs and medical advisers of insurance companies are provided with a manageable protocol of approach and treatment leading, in due course, to a situation which is comparable with the situation which exists in other countries. Unnecessary examinations, such as Magnetic Resonance Imaging (MRI), etc. and unnecessary treatment can be prevented if every treating physician were to work from the very beginning along the lines of the generally recognised protocol. In daily practice it is sometimes seen that as a result of for example the unnecessary use of a neck collar, and on top of that incorrectly so for too long a period of time, an irreversible and severely disabling loss of function of the neck develops. Additionally, many patients have unnecessarily remained "in the dark", because they have been successively confronted with different treatments, differing advice or differing treatments which were all branded as the only and correct remedy. Those patients have become unnecessarily unsure, unnecessarily less able for employment or, in other words, unnecessarily disabled.

That is reason why prevention in the medical field is the most important aspect of the Canadian report. This prevention can be summarised as follows ${ }^{54}$ :

- all doctors should follow the same intake procedure

- give enough attention to your patient

- establish in which category your patient falls after a geared anamnesis and examination

- give clear advice. In most cases this will be: "Stay active, let your body be the guide to what you can and cannot do"

- by giving sound councelling, a situation can be prevented whereby longer lasting complaints lead to lasting illness, respectively permanent disability

- do not carry out or refer to unnecessary examinations

- do not dissuade patients from necessary therapy.

${ }^{54}$ See also W. J. Oosterveld. Diagnostiek en bahendeling bij whiplash; Whiplash Rapport (publication of the NSWP, December 1995, p. $16 \mathrm{ff}$. 


\section{The claim settlement procedure in whiplash claims}

Consensus has gradually been reached in the Netherlands ${ }^{55}$ about the fact that a - possibly - quick claim settlement is advantageous to all parties. This applies in particular to whiplash claims, because the so-called frustration damage can thereby be avoided as much as possible. After all, the frustration component arises especially with a feeling of lack of recognition by the victim, generally in combination with an arduous claim settlement. The victim might consequently present himself more and more as a patient, which may bring about some three side effects, all of which will lead to an increased claim burden (the so-called claim inflation).

- More medical "shopping around" will take place in order to find acknowledgement by the medical profession for the incapacitating existence of the complaints, which may lead to the development of the "victim syndrome" 56 ; this can have an incapacitating effect and generates, in any case, extra medical costs.

- The normal healing process may be disrupted by e.g. the insurer of the responsible party, but also by the victim's environment, causing longer absenteeism from work.

- The victim (and often his legal representative too) adopt a harder attitude towards the insurer and care consequently less susceptible to possible settlement proposals from that quarter. This hardening will generally lead to a higher (frustration) claim.

It would therefore be a good thing if the third party liability insurer of the responsible party (and in effect also the "real" responsible party, i.e. the other driver) were to show an interest in the victim and establish contact. This could in first instance often be done over by telephone. In such a conversation by phone the claims negotiator could raise various items, such as:

- express an interest (very simply put: "How are you doing?");

- ask whether costs have been incurred;

- gather information which might be of relevance to the medical trajectory - possibly to be initiated by the insurer - (e.g. is a medical examination required, or will information from the treating physician(s) suffice for the time being).

Especially in those cases where liability is not at issue, it is imperative to make an advance payment quickly (subject to losses having been incurred, of course).

In addition it is important to have a field inspector visit the victim as soon as possible (something that must be allowed by a - possible - legal representative of the victim) in order to obtain extensive information about the circumstances of the accident and to record the victim's so-called medical/social biography. In fact, in making good "medical" damage, it is all too often forgotten that not only the end situation is of importance, but also the starting point. With a view to both prevention and claim settlement, extensive fact-finding ${ }^{57}$ (preferably by means of a set questionnaire) is essential. Next, the actual settlement of the claim should be undertaken expediently (and contact with the victim maintained on a

${ }_{55}$ This was borne out in particular during the introductions and discussions at the Audalet-congress in Zeist on 10th May 1995.

${ }^{56}$ See also G. F. Koerselman during his introduction at the AMC-congress on 17 th November 1995, entitled "Psychiatrische aspecten van het postwhiplash-syndroom".

${ }^{57}$ In Germany (at the German Insurers' Association) extensive data bases with information on the circumstances of the accident, are available. 
regular basis) and should - especially - the lighter whiplash claims be settled for more or less standardized amounts for e.g. pain and suffering. In doing so, it might be desirable to divise whiplash claims into a number of categories. ${ }^{58}$ Further plans should be worked out between the liability insurers and the professional legal aid providers about this, for example:

a) slight injuries without - or with only negligible - incapacity;

b) slight injuries with an incapacity lasting less than 2 weeks;

c) less serious injuries with an incapacity lasting between 2 and 6 weeks;

d) (less) serious injuries with an incapacity lasting between 6 and 13 weeks;

e) serious injuries with an incapacity in excess of 3 months.

\section{Conclusions and recommendations}

It may have become paramount from the previous chapters that the whiplash phenomenon is not an issue that stands on its own; there exists collation with the technical field, the medical science (with respect to both diagnosis and therapy, the law (in particular the problem of causation) and the claim settlement procedure.

Until now, there are suppositions only as to what causes the physical complaints; a cure/ therapy has not yet been found. In addition, there are great differences between countries. The Dutch figures for traffic related whiplash injuries mentioned in chapter 2 (approximately 15,000 claims; burden \pm Dfls 300 million) are rather in contrast with the German figures: $\pm 400,000$ claims, estimated value DM 1 billion. ${ }^{59}$ In view of the complexity of the subject matter, multi-disciplinary research and cooperation (also internationally) seems to be necessary. The extent of the whiplash phenomenon - both in the number of victims and in the money involved - calls for immediate action (fortunately already partly under way), also in view of the possibly to be expected influx of claims relating to other medically non-objectifiable abnormalities (such as minor head injuries).

Seen from this context, whiplash is also a social and sociological problem, possibly in part inherent to the "spirit" of the nineties.

This leads to the following recommendations:

a) more attention from the car industry for whiplash prevention. In this the (positioning of the) head restraints will have to play a key role, but also aspects such as the quality of the car seat, the seating position behind the wheel, airbags and deformations zones need to be addressed. Further European legislation ${ }^{60}$ on this would appear necessary. The Netherlands, Germany and the Scandinavian countries could play a leading role here. For the insurers too, prevention could become of extra relevance in case of a possible

58 N. Muntjewerff (solicitor and member of the NSWP network) in this introduction on the Vermande workshop in Utrecht on 31 st October 1994 advocated a tripartition: light, medium and severe.

${ }^{59}$ According to a statement by the Verband der Schadenversicherer; communicated during discussions in Munich on 16th January 1996.

${ }^{60}$ In the TNO-report by Wismans and Huijskens (chapter 4. European legislation) this is discussed in depth. The present European guidelines on head restraints date from the seventies! 
transgression from a third party to a (partly) first party system. ${ }^{61}$ In this, preventive measures could become an underwriting, respectively a premium factor; similar to the present system of anti-theft prevention for comprehensive motor policies. Under the present third party system, a premium discount for a "whiplash-safe" car does not really fit (it is after all generally the insurer of "the other car" that has to pay). General preventive measures for road safety as proposed by the Quebec Task Force (see chapter 3) are to be recommended.

b) Further scientific research would seem necessary. The current RAND/TUD research ${ }^{62}$ must give a first impetus here. To this end, extensive claim file research is necessary, so that a measuring tool can be developed in order to process the information from the files in a standardized fashion, directed at four perspectives:

1. the characteristics of the traffic accident that lay at the origine of the claim (e.g. make and size of the car, its speed, place in the vehicle of the injured party in case injuries were sustained, circumstances, etc.).

2. The personal and demographical circumstances of the claimant.

3. When and whether various parties (GPs, specialist/consultants, solicitors, police) were involved in the claim and the duration of the various phases of the claim (the time from the date of the accident until the completion of the claim, interim processes).

4. The medical characteristics of the claim, for example along the lines of the method as developed in the course of the research by the Quebec Task Force.

The outcome of such a study could then also be of interest for the claim settlement procedure of other non-objectifiable complaints. Here too, an international approach seems desirable, of course taking into account typical "national" aspects, such as the mentality and the various legal systems.

c) In the short term consensus must be reached in the medical (and para-medical) world about medical prevention, aimed at adequate care and treatment of whiplash victims. ${ }^{63}$ The Canadian report by the Quebec Task Force offers very good openings hereto. The GP will have to play a guiding role in this. The various medical, para-medical and psychological specialisms will also have to gather forces. ${ }^{64} \mathrm{It}$ must be avoided that the whiplash phenomenon is allowed to become "commercialised".

${ }^{61}$ It is certainly not to be excluded that the Ontwerpwetgeving Verkeersaansprakelijkheid (Preliminary version of Bill on Traffic liability) which is expected shortly, will be based on compulsory Schadeverzekering voor Inzittenden (Policy against material and immaterial losses for passengers); see hereto the reply by the Minister of Justice dated 1st November 1995 to questions of the Vaste Commissie voor Justitie of the Tweede Kamer (21528 nr. 6) p. 2.

62 See also chapter 3, last paragraph; the result of the pilot-study which is presently under way, can be expected in the beginning of 1997; hopefully this will lead to a(n) (international) follow-up study.

63 The initial impetus to this has already been given by the Wetenschappelijke Raad of the NSWP, under the chairmanship of Prof. W. Oosterveld.

${ }^{64}$ See also Oosterveld, loc. cit., p. 18. 
d) Experience abroad ${ }^{65}$ has learnt that there is a norrow link between the claims behaviour and the legal system. Especially with regard to causation, it must be reassessed whether in the Netherlands we have not gone too far in this, also in view of the aspects which are typical to a whiplash claim. The application of art. 6:101 of the Civil Code for whiplash victims in case of wrongfully positioned head restraints, is not to be precluded in the future, especially in case of further publicity about whiplash prevention.

Further elaboration on this both in the legal doctrine and the jurisprudence is, however, necessary for this, in the course of which matters such as (complete) attribution (i.e. a degree of contributory negligence), uncertainty as to causation, the statistical causation ${ }^{66}$ maybe have to be viewed in a different perspective. Furthermore, the parties in the market (i.e. the insurers and the professional legal aid providers) will have to develop new tools, which might contribute to a quicker and more efficient claim settlement procedure, such as a classification and standardisation.

All in all, there is still a lot of work and effort in line for us. However, in view of the complexity of the whiplash phenomenon this is completely justified.

To that end, insurers, technicians, the medical profession, lawyers and other people from other disciplines will to have to climb down from their - possibly - ivory towers and enter new avenues of cooperation; in short, we must dare to stick out our necks!

65 Apart from the cited German (and Canadian) situation, an example from Australia is also worth mentioning. The number of claims has dropped considerably there, since the claimant had to pay a guarantee of Austr. $\$ 400$.

66 See also Faure/Hartlief, loc. cit., p. 25 and the literature mentioned there. 